\title{
OVARIAN DYSGERMINOMA CAUSING MULTIFOCAL METASTASES IN YOUNG BITCH
}

\author{
DISGERMINOMA OVARIANO CAUSANDO METÁSTASES MULTIFOCAIS \\ EM CADELA JOVEM
}

\author{
Fernanda Gosuen Gonçalves DIAS ${ }^{1^{*}}$; Larissa Fernandes MAGALHÃES ${ }^{1}$; \\ Geórgia Modé MAGALHÃES ${ }^{1}$; Tais Harumi de Castro SASAHARA ${ }^{1}$; \\ Lucas de Freitas PEREIRA ${ }^{\mathbf{1}}$; Sabryna Gouveia CALAZANS'; \\ Luis Gustavo Gosuen Gonçalves DIAS ${ }^{1}$; Luara Rodrigues REZENDE ${ }^{1}$ \\ 1. UNIFRAN - University of Franca, Parque Universitário, Franca, SP, Brazil. *fernandagosuen@ yahoo.com.br
}

\begin{abstract}
The ovarian neoplasias are unusual in canine species, mainly originated from germinative cells. Among these, dysgerminoma is a rare neoplasm in bitches, predominantly affecting senile and small and medium breeds. They are large, rounded, smooth surface, painless and firm in consistency. The clinical signs commonly demonstrated by patients with this neoplasia are abdominal distension and secondary signs of hyperestrogenism. The diagnosis should be based on the association of history, clinical signs, radiographic, ultrasonographic, cytological, histopathological and immunohistochemical exams. The treatment is the surgical castration and metastases are uncommon. Due to the rarity in bitches, specifically the young animals, this study aimed to describe a case of left ovarian dysgerminoma, of considerable size and adherence in adjacent organs, in a Brazilian Fila, whose showed considerable increase in abdominal volume and progressive weight loss. The diagnosis was confirmed by means of complementary x-ray, ultrasound, histopathological and immunohistochemical tests. Even with the recommended surgical treatment (castration), the patient demonstrated severe respiratory symptoms and increased abdominal volume after two months, and the complementary exams suggested pulmonary and multifocal metastases and the tutor chose euthanasia. As presented by the results, although rare in bitches, dysgerminoma should be included in the differential of ovarian neoplasias, including the young ones.
\end{abstract}

KEYWORDS: Germinative cells. Gonadal alteration. Ovarian neoplasia.

\section{INTRODUCTION}

Primary ovarian neoplasms are rare in bitches (ROLIM et al., 2010), representing only 0.5 to $1 \%$ of all neoplasia in the canine species (CARDILLI et al., 2007). They usually affect adult females to the elderly and the etiopathogenesis is not completely elucidated (MAGALHÃES et al., 2008). Some are able to produce hormonal activity and, most of the times, demonstrate unilateral impairment (LANNA et al., 2012). The most predisposed breeds are the Bulldog, Yorkshire, Boxer, German Shepherd and Lhasa Apso (CARDILLI et al., 2007).

Among the ovarian neoplasms, germ cell tumors are formed by primordial ovarian germ cells (BERTAZZOLO et al., 2004), and in this context, dysgerminoma is rare in canines (AZIZI; KHEIRANDISH; SAMI, 2015), representing only $6-12 \%$ of ovarian tumors in this species (NOVOTNY et al., 2011). The histogenesis of dysgerminoma is still unknown and controversial (GAUZA et al., 2010), since it presents a typical testicular seminoma (ZEZZA NETO et al., 1968; MEUTEN, 2017). Adult females (10 years of age or older) (PARK et al., 2009) and of small and medium breeds are the most affected (GREENLEE; PATNAIK, 1985).

The clinical signs found in bitches with dysgerminoma include abdominal distension and pain, ascites (ROLIM et al., 2010), anorexia, polyuria, polydipsia, vomiting, weight loss, diarrhea, lethargy (NOVOTNY et al., 2011) and peritonitis secondary to torsion and neoplastic ulceration (PECTASIDES et al., 2008). Signs of hormonal dysfunction (prolonged estrus, secretion and vaginal swelling, cystic endometrial hyperplasia and pyometra) are not always present (SILVA et al., 2004).

The diagnosis is based on clinical signs, radiographic and ultrasonographic images and cytological, histopathological and immunohistochemical exams. The treatment of choice is ovariosalpingohisterectomy (ANTONOV; FASULKOV; SIMEONOV, 2014) and adjuvant chemotherapy is only recommended in cases of 
metastases, which are rare in this tumor type (CARDILLI et al., 2007).

Due to the rare occurrence in bitches, especially in the young, the present study aimed to describe a case of ovarian dysgerminoma and to correlate the unfavorable prognosis with the occurrence of metastases in both lungs as well as in adjacent organs.

\section{CASE REPORT}

This study was approved by the Ethics Committee on the Use of Animals (CEUA) of the University of Franca (UNIFRAN-SP) (case $n^{\circ}$ 019/14).

A four-year, $33 \mathrm{~kg}$ unneutered Fila Brasileiro bitch was treated at the UNIFRAN Veterinary Hospital with increased abdominal volume and weight loss two weeks ago, even with normorexia. She had a distocic delivery and last estrus two months ago without any administration of progestins. Physical examination showed significant increase in abdominal volume (generalized, rounded, firm and painless consistency). Hematological examinations presented reference values for the species. Abdominal and chest x-rays showed, respectively, a large circumscribed abdominal mass and absence of areas suggestive of pulmonary metastases. Ultrasound showed a heterogeneous abdominal mass, $20 \mathrm{~cm}$ in diameter, smooth surface, involving meso and right and left hypogastric, with cavitations in the right cranial region, but due to its large extension and the no anatomical visceral position, it was not possible to define the organ of origin. Ultrasound-guided aspiration biopsy was performed, which was inconclusive.

The patient was submitted to the exploratory laparotomy, showing a mass in the left ovary (Figure 1) with areas of adhesion in the major omentum, spleen and stomach. Ovariosalpingectomy was performed and fragments of the nodule were submitted to histopathological examination at the Laboratory of Animal Pathology of the same institution, which confirmed the diagnosis of dysgerminoma (Figure 2).

The immunostaining for estrogen and progesterone was negative (Figure 3 ).

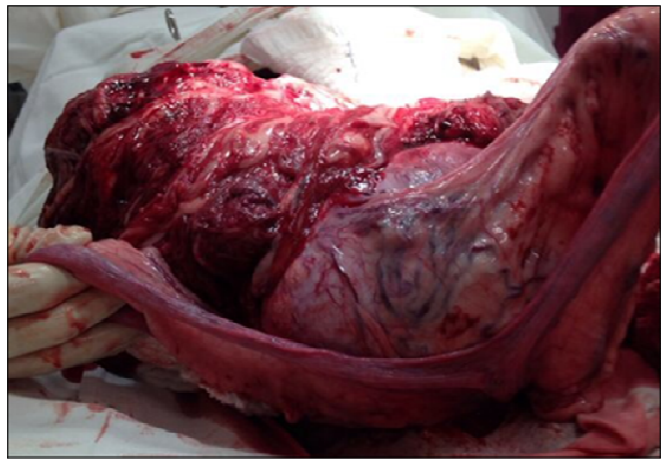

Figure 1. Photographic image of the ovariosalpingohisterectomy trans-surgical in bitch with left ovarian mass, approximately $20 \mathrm{~cm}$ in diameter, smooth surface, covering a large part of the abdominal region. A whitish, non-ulcerated mass with adhesions on adjacent organs.

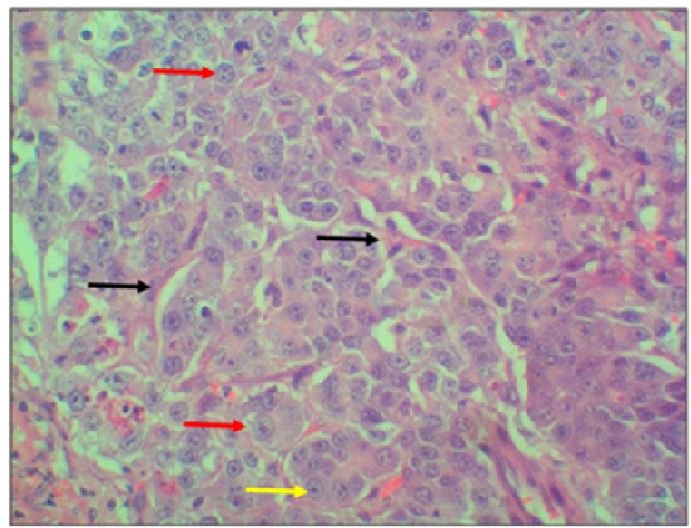

Figure 2. Photomicrography of canine ovarian dysgerminoma. Observe a highly cellular neoplasm consisting of nests of cells, separated by thin septa of connective tissue (black arrows). Tumor cells resemble primitive germ cells (red arrows). Such cells are large and polyhedral, with vesicular nucleus and evident nucleoli (yellow arrow) and scarce cytoplasm (H.E. Obj. 40x). 


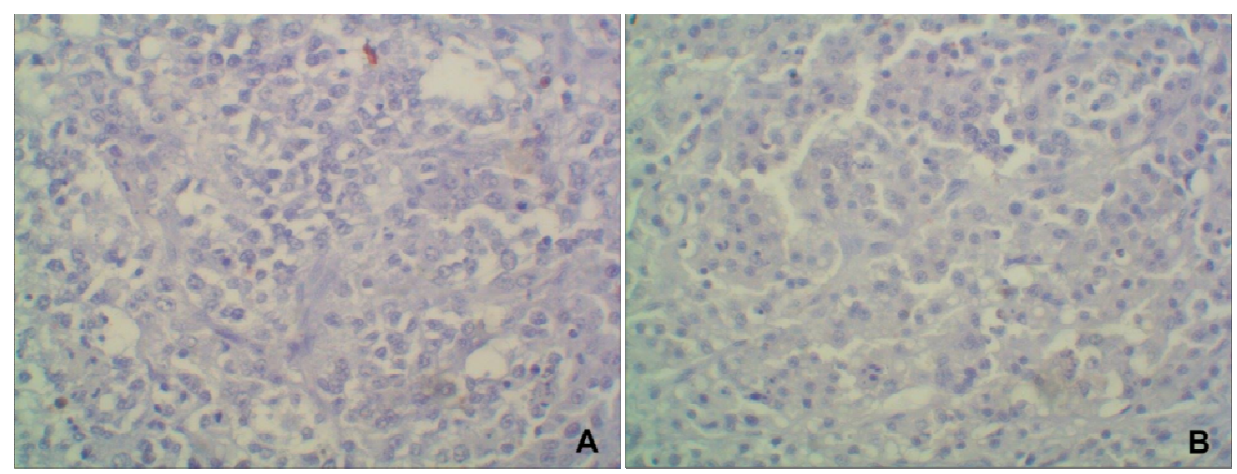

Figure 3. Photomicrographs of immunostaining for hormone receptors in canine ovarian dysgerminoma by the Reveal method: A) absence of immunostaining for estrogen, biotin-free, DAB chromogen, obj. 40x. B) absence of immunostaining for progesterone, biotin-free, DAB chromogen, obj 40x.

In the postoperative was prescribed antibiotic, anti-inflammatory, gastric protector and systemic analgesic, in addition to topical dressings and elizabethan collar. Ten days after the procedure, the surgical sutures were removed and the owner was informed about the periodic visits to evaluated the case. After two months, the animal returned with dyspnea and increased abdominal volume. The thoracic $\mathrm{x}$-rays suggested pulmonary nodulations and the abdominal ultrasound suggested nodulation in mesentery and major omentum. The owner decided to euthanasia the animal, authorizing the necropsy. Multifocal metastases (pulmonary lobes, mesentery, major omentum and diaphragm) were confirmed and pulmonary histopathology confirmed the primary origin of dysgerminoma in the ovary (Figure 4).

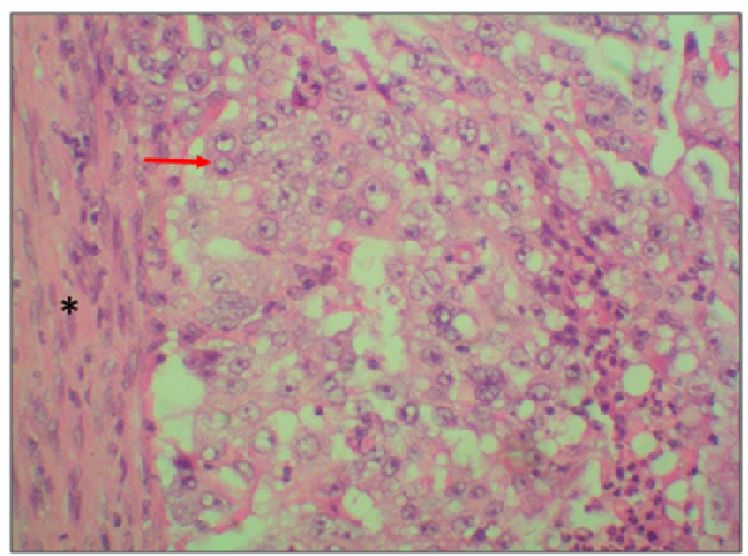

Figure 4. Photomicrography of pulmonary metastasis of canine ovarian dysgerminoma. Tumor cells similar to the primitive germinatives, characterized by being large, scarce cytoplasm, vesicular nucleus and evident nucleolus (arrow). Presence of connective tissue septa (*) (H.E. Obj. 40x).

\section{DISCUSSION}

Germ cell tumors consist of tumor originated from primordial germ cells that migrate from the yolk sac to the primitive gonadal ridge and become embedded in the primary sex cords. These tumors are rare in canine species (ZEZZA NETO et al., 1968; ROLIM et al., 2010) and it can be attributed to the significant increase of early castration, a low investigation of this tumor type by the veterinarians, an incomplete reproductive history reported by the tutors (LANNA et al., 2012) and to the fact that some patients are asymptomatic, as described by Rolim et al. (2010) and Novotny et al.
(2011), that the tumor may be an accidental finding during castration.

Thus, although uncommon, dysgerminoma (MEUTEN, 2017) occurs more frequently in bitches than in other domestic species (ZEZZA NETO et al., 1968; MAGALHÃES et al., 2008). However, Andrews et al. (1974) reported it in cats with bilateral ovarian involvement. In contrast, dysgerminoma is the most predominant germ cell tumor in young women (GAUZA et al., 2010, KUMAR et al., 2012) and may occur during the gestational period (PECTASIDES et al., 2008).

The formation and development of the different embryonic tissues involved in 
dysgerminoma are not clear, and according to Zezza Neto et al. (1968) and Gauza et al. (2010), it is not known whether the neoplasm is composed of ovarian germ cells with seminoma-like growth pattern or if it is a seminoma formed of male germ cells in a bisexual ovary.

In accordance with Radhakrishna et al. (2001) and Cardilli et al. (2007), the patient reported showed unilateral ovarian involvement. On the other hand, race and size did not coincide with those reported by these same authors. Moreover, differing from the reported by Bertazzolo et al. (2004) and Park et al. (2009), the current patient was only four years old.

Although cases of bilateral dysgerminomas are poor in the literature, Rolim et al. (2010) reported it in a mixed-breed adult female, associated with cystic endometrial hyperplasia and pyometra. However, such authors have pointed out that these joint reproductive alterations are frequent in cases of ovarian neoplasms of stromal origin of sexual cords and not of germ cells. In this context, Azizi, Kheirandish and Sami (2015) reported the occurrence of bilateral ovarian dysgerminoma in young goat, concomitant with true hermaphroditism.

The macroscopic, microscopic, radiographic and ultrasonographic aspects of the dysgerminoma of the patient in question corroborated exactly with the scientific descriptions (BERTOLZ et al., 2004, CARDILLI et al., 2007, NOVOTNY et al., 2011, ANTONOV; FASULKOV; SIMEONOV, 2014; MEUTEN, 2017).

The ovarian histopathological examination was essential in the diagnosis of the reported patient (ANDREWS et al., 1974; MAGALHÃES et al., 2008), since the dysgerminoma must be differentiated from other neoplasias and ovarian affections such as lymphosarcoma, solid adenocarcinoma, solid granulosa cells tumor, theca tumor, teratoma and non-functional ovarian cysts, as indicated by Park et al. (2009) and Rolim et al. (2010). Continuing the diagnosis, Park et al. (2009) and Rolim et al. (2010) suggested immunohistochemistry for cytokeratin and vimentin when the histopathological examination did not distinguish the tumor type. In contrast, Radhakrishna et al. (2001) stated that dysgerminomas do not secrete specific tumor markers, and that a positive result for cytokeratin may be related only to the anaplastic tumor characteristic.

By the fact that endogenous sex hormones are among the factors that induce or promote carcinogenesis, it was decided in the present case to investigate the immunostaining for estrogen and progesterone receptors, since according to Silva et al. (2004), the hormone-dependent neoplasms show a better prognosis in humans when compared to those who have already acquired hormonal independence. However, due to the negative results, it is assumed that the neoplastic progression, with consequent increase in the malignancy degree, was responsible for the occurrence of multifocal metastases. In addition, adherence to adjacent organs and excessive manipulation of neoplasia during the surgical procedure (due to its extension) may have predisposed the spread of neoplastic cells into the abdominal cavity, as described by Novotny et al. (2011), which made the prognosis unfavorable.

Probably because the dysgerminoma secondary metastases were not frequent in dogs (PARK et al., 2009; ROLIM et al., 2010), there are no scientific references regarding the chemotherapy treatment concomitant to the surgical in this animal species, but in humans, Radhakrishna et al. (2001) prescribes it in all cases after surgery, which have bilateral ovarian involvement. These authors suggested a protocol with bleomycin, cisplatin and etoposide after three weeks of surgery (four sessions, in total, with intervals of 21 days between them) because they demonstrated promising results regarding the absence of relapses and patient survival. In dogs, Novotny et al. (2011) reported the possibility of radiotherapy in cases where surgical treatment is contraindicated, justifying the fact that dysgerminomas are histologically similar to seminomas and these are effectively responsive to such therapeutic protocol.

Due to the rarely studies in the veterinary literature about the dysgerminoma in bitches (NOVOTNY et al., 2011), it is difficult to define some etiological factors involved, the disease staging, adjuvant therapeutic modalities and those correlated with prognosis, that became difficult the comparison among authors.

\section{CONCLUSION}

Based on the clinical case and despite the fact that is not a common disease in canine species, dysgerminoma should be included in the differential diagnosis of ovarian neoplasms, included young patients. In addition, future research aimed at correlating the prognosis of dysgerminoma in bitches with the absence of hormonal immunostaining will be essential to new therapeutic approaches, such as the administration of antagonistic hormones and/or anti-hormonal drugs. 
RESUMO: As neoplasias ovarianas são de ocorrência incomum na espécie canina, principalmente as originadas de células germinativas. Dentre estas, o disgerminoma é uma neoplasia rara em cadelas, acometendo predominantemente fêmeas senis e de raças pequenas e médias. Apresentam-se como massas grandes, arredondadas, de superfície lisa, indolores e de consistência firme. Os sinais clínicos comumente demonstrados por pacientes com este tipo neoplásico incluem distensão abdominal e sinais secundários de hiperestrogenismo. O diagnóstico deve ser baseado na associação do histórico, sinais clínicos, exames radiográficos, ultrassonográficos, citológicos, histopatológicos e imunohistoquímicos. O tratamento de escolha é a castração cirúrgica, sendo que as metástases são incomuns. Perante a raridade em cadelas, em específico as jovens, este relato teve como propósito discorrer um caso de disgerminoma ovariano esquerdo, de tamanho considerável e aderência em órgãos adjacentes, em uma Fila Brasileira, cuja sintomatologia incluiu considerável aumento de volume abdominal e emagrecimento progressivo. O diagnóstico foi confirmado por meio de exames complementares de raios-x, ultrassom, histopatológico e imunohistoquímicos. Mesmo com a instituição do tratamento cirúrgico preconizado (castração), a paciente demonstrou grave sintomatologia respiratória e aumento de volume abdominal após dois meses e, como os exames complementares foram sugestivos de metástases pulmonares e multifocais, o tutor optou pela eutanásia. Diante dos resultados, pode-se admitir que apesar de raro em cadelas, o disgerminoma deve ser incluído no diferencial das neoplasias ovarianas, incluindo as jovens.

PALAVRAS-CHAVE: Células germinativas. Alteração gonadal. Neoplasia ovariana.

\section{REFERENCES}

ANDREWS, E. J.; STOOKEY, J. L.; HELLAND, D. R.; SLAUGHTER, L. J. A histopathological study of canine and feline ovarian disgerminomas. The Canadian Journal of Comparative Medicine, v. 38, n. 1, p. $85-89,1974$.

ANTONOV, A.; FASULKOV, I.; SIMEONOV, R. A clinical case of unilateral ovarian dysgerminoma and pyometra in a bitch. Macedonian Veterinary Review, v. 37, n. 2, p. 179-183, 2014.

https://doi.org/10.14432/j.macvetrev.2014.04.013

AZIZI, S.; KHEIRANDISH, R.; SAMI, M. Occurrence of bilateral dysgerminoma in a true hermaphroditism goat. Comparative Clinical Pathology, v. 24, n. 1, p. 469-472, 2015. https://doi.org/10.1007/s00580-0141985-8

BERTAZZOLO, W.; DELL'ORCO, M.; BONFANTI, U.; DELORENZI, D.; MASSERDOTTI, C.; MARCOS, B.; CANIATTI, M.; ROCCABIANCA, P. Cytological features of canine ovarian tumours: a retrospective study of 19 cases. Journal of Small Animal Practice, v. 45, n. 1, p. 539-545, 2004. https://doi.org/10.1111/j.17485827.2004.tb00200.x

CARDILli, D. J.; TONIOLlO, G. H.; MOSTACHIO, G. Q.; MOTHEO, T. F.; LIMA, I. G. F.; VIVENTE, W. R. R. Disgerminoma ovariano em cadela: relato de caso. Clínica Veterinária, v. 7, n. 66, p. 64-66, 2007.

GAUZA, J. E.; REBERTI, A. G.; SILVA, J. C.; POPE, L. Z. B.; SANTOS, J. C. R.; QUINTANA, S. M. Diagnóstico de disgerminoma durante a gestação. Revista da Associação Médica Brasileira, v. 56, n. 5, p. 517-519, 2010. https://doi.org/10.1590/S0104-42302010000500009

GREENLEE, P. G.; PATNAIK, A. K. Canine ovarian tumors of germ cells origin. Veterinary Pathology, v. 22, n. 1, p. 117-122, 1985. https://doi.org/10.1177/030098588502200204

KUMAR, S.; KUMAR, L.; KARMAKAR, D.; SAFAYA, R.; DURGAPAL, P. Dysgerminoma in the uterine cervix. International Journal of Gynecology and Obstetrics, v. 116, n. 1, p. 83-84, 2012.

https://doi.org/10.1016/j.ijgo.2011.07.034 
LANNA, L. L.; MASCARENHAS, R. M.; MARQUES JÚNIOR, A. P. Abordagem clínica da infertilidade na cadela e patologias associadas: revisão. Revista Brasileira de Reprodução Animal, v. 36, n. 2, p. 113-121, 2012.

MAGALHÃES, G. M.; OLIVEIRA, S. A.; MARTINELLI, P. E. B.; VARASCHIN, M. S.; VASCONCELOS, R. O. Disgerminoma em cadela: aspectos clínicos e patológicos. Relato de caso. Veterinária e Zootecnia, v. 15 , n. 3, p. 36-37, 2008.

MEUTEN, D. J. Tumours in Domestics Animals. 5. ed. Wiley-Blackwell, 2017. 1000p.

NOVOTNY, R.; VITASEK, R.; BARTOSKOVA, A. Ovarian dysgerminoma with retroperitoneal metastases in a bitch: a case report. Veterinarni Medicina, v. 56, n. 3, p. 140-144, 2011. https://doi.org/10.17221/3157VETMED

PARK, J. K.; GOO, M. J.; HONG, I. H.; KI, M. R.; HAN, J. Y.; JEONG, K. S. Immunohistochemistry diagnosis of an ovarian dysgerminoma in one bitch. Reproduction in Domestic Animals, v. 44, n. 1, p. 855858, 2009. https://doi.org/10.1111/j.1439-0531.2008.01135.x

PECTASIDES, D.; PECTASIDES, E.; KASSANOS, D. Germ cells tumors of the ovary. Cancer Treatment Review, v. 34, n. 1, p. 427-441, 2008. https://doi.org/10.1016/j.ctrv.2008.02.002

RADHAKRISHNA, S.; HAQ, S.; LOFTS, F.; YOUNG, M. P. A.; BARTON, D. P. J. Ovarian dysgerminoma presenting with hypercalcaemia. British Journal of Obstetrics and Gynaecology, v. 108, n. 1, p. 1302-1304, 2001. https://doi.org/10.1016/S0306-5456(01)00286-8

ROLIM, V. M.; PINTO, T. M.; LOPES, L. M. A.; SONNE, L.; OLIVEIRA, E. C.; ALMEIDA, P. R.; BECK, C. A. C.; DRIEMEIER, D. Disgerminoma bilateral e hiperplasia endometrial cística com piometra em cadela. Acta Scientiae Veterinariae, v. 38, n. 3, p. 337-340, 2010. https://doi.org/10.22456/1679-9216.17519

SILVA, A. E.; SERAKIDES, R.; CASSALI, G. D. Carcinogênese hormonal e neoplasias hormôniodependentes. Ciência Rural, v. 34, n. 2, p. 625-633, 2004. https://doi.org/10.1590/S0103-84782004000200048

ZEZZA NETO, L.; GRECCHI, R.; SALIBA, A. M.; MARIANO, M. Disgerminoma do ovário em cadela. Revista da Faculdade de Medicina Veterinária de São Paulo, v. 7, n. 4, p. 923-927, 1968.

https://doi.org/10.11606/issn.2318-5066.v7i4p923-928 